\title{
Assessment of Poverty Index in Delta State, Nigeria
}

\author{
Ike, P. C. and Aberji, D. O. \\ Dept. of Agricultural Economics \& Extension, Delta State University, Asaba Campus, P.M.B 95074 Asaba, \\ Nigeria
}

\begin{abstract}
The broad aim of this study was to conduct a poverty index survey in Delta State, Nigeria by determining the indices of education, health and standard of living, and the proportion of the population that lives below poverty line as well as socioeconomic factors that affect poverty. Data were generated from 450 households selected from 30 communities in 15 LGAs of the State and analysed using descriptive statistical tools while Foster Greer and Thorbecke (1984) model was used to estimate poverty incidence. Binary Probit model was applied to analyse determinants of poverty. Results revealed that $2.63 \%$ of the households are educationally deprived while infant mortality was low (1.7). 5.99\% households live in an accommodation considered deprived (poverty) with less than $60 \%$ having access to safe drinking water and $52.35 \%$ households living in unimproved sanitation. The total annual household income ranged from N100,000 (\$277.78) to N700,000 $(\$ 1,944.44)$ with $24.09 \%$ living below core poverty level while in all, $70 \%$ was relatively poor and could not attain the minimum standard of living. The main source of income to the respondents was farming activities (38.05\%) while $73.4 \%$ of total monthly households' expenditure was on food. Access to microcredit, education, workshops/seminars, livestock asset, and extension services significantly influence the probability of households exiting chronic poverty. On the other hand, female headed households and distance to the market as well as large family size increases the probability of persistence in chronic poverty. State government should intervene more aggressively in rural development through increased provision of rural infrastructure such as rural roads, water schemes, rural electrification and rural health schemes.
\end{abstract}

Keywords: Poverty, Index, Determinants, Socioeconomic, Households, Delta State

\section{Introduction}

Poverty is a great enemy to human happiness, it certainly destroys liberty and makes some virtues impracticable and others extremely difficult. Absolute poverty is a condition of life so limited by illiteracy, malnutrition, disease, high infant mortality and low life expectancy as to prevent realization of the very potentials of human genes with which one is born. It is life at the margin of existence. Poverty is present when basic capability failure arises because a person has inadequate command over resources, whether through market or non market sources.

Nigeria has one of the greatest development potentials in Africa given the vastness of her resources and above all her rich human resource endowment. But regardless of these potentials Nigeria is still among the poorest countries of the world. The economy is mired by multiple difficulties. On the basis of widespread economic crisis, and the recent global economic meltdown, the country is unable to raise the standard of living of its citizens to an appreciable height. Thus poverty, in both absolute and relative terms, constitutes one of the most serious problems confronting Nigeria. Statistically, between 1960 and 1980, the poverty level covered about 28.0 percent of the population; by 1996 it rose alarmingly to about 66 percent of the population (Aliju, 2001).

Poverty in Nigeria has been described from different dimensions. Despite several attempts by successive governments to ameliorate the scourge, the level of poverty has been geometrically increasing (Eze, 2009). Poverty is deep and pervasive, with about 70 percent of the population living in absolute poverty (OkonjoIweala, Soludo and Muhtar, 2003). 
Nigeria presents a paradox of being a rich country but the people are poor. An analysis of the context reveals that poverty holds sway in the midst of plenty. Nigeria is the eight largest oil producing country in the world but it harbours the largest population of the poor people in sub-Saharan Africa, and is ranked 158th on Human Development Index (HDI). There is equally pervasive high-income inequality, which has perpetuated the concentration of wealth in the hands of few individuals.

Poverty is more easily recognized than defined; hence a universally accepted definition of the term poverty has remained elusive. However, poverty can be regarded as the inability to adequately meet the basic human necessities such as food shelter clothing and Medicare (UNDP, 2014).

According to the United Nation Development Program Human Development Report (2008-2009) which combined such components as; level of inequality, life expectancy at birth, standard of living and access to knowledge, and education, between 2004 and 2009 poverty in Nigeria has worsened from 0.43 to 0.49 . This shows that despite its vast resources, Nigeria ranks among the 25 poorest countries of the world. In fact, poverty has been a serious challenge to governments in Nigeria. Its effect, which includes lack and deprivation in the basic necessities of life, is worrisome.

According to Eweniyi 2018, Nigeria has one of the world's highest economic growth rates, averaging 7.4\% (according to the Nigeria economic report released in July 2014 by the World Bank) but over 80 million Nigerians - $42.4 \%$ of the population - currently live below the poverty line, according to the United Nations release. By February 2018, Nigeria overtook India as the country with the most people in extreme poverty. For context, India has 5 times the population of Nigeria. According to World Bank standards, living in extreme poverty is living on less than $\$ 1.90$ (N680) per day. People living in extreme poverty are unable to meet even the barest minimal needs for survival.

In 2015, the UN set up the Sustainable Development Goals, and the first of them is to "eradicate extreme poverty for all people everywhere by 2030". However to achieve this globally, 90 people need to leave poverty every minute to eradicate poverty totally by 2030; and to achieve this in Africa, 57 people have to leave every minute; and in Nigeria, 12 people per minute. As it can be imagined, this is not the case. In fact the opposite is the case. On the average, 9 people are entering extreme poverty every minute, and Nigeria and the Democratic Republic of Congo are both responsible for the 9. And individually, Nigeria has about 7 people going into poverty every minute (Eweniyi, 2018).

Table 1: Relative Poverty: Non Poor; Moderate Poor and Extremely Poor (\%), 1980- 2010

\begin{tabular}{llll}
\hline Year & Non-Poor & Moderately Poor & Extremely Poor \\
\hline 1980 & 72.8 & 21.0 & 6.2 \\
1985 & 3.7 & 34.2 & 12.1 \\
1992 & 57.3 & 28.9 & 13.9 \\
1996 & 34.4 & 36.3 & 29.3 \\
2004 & 43.3 & 32.4 & 22.0 \\
2010 & 31.0 & 30.3 & 38.7 \\
\hline
\end{tabular}

Source: NBS, Harmonized Nigeria Living Standard Survey, 2010 


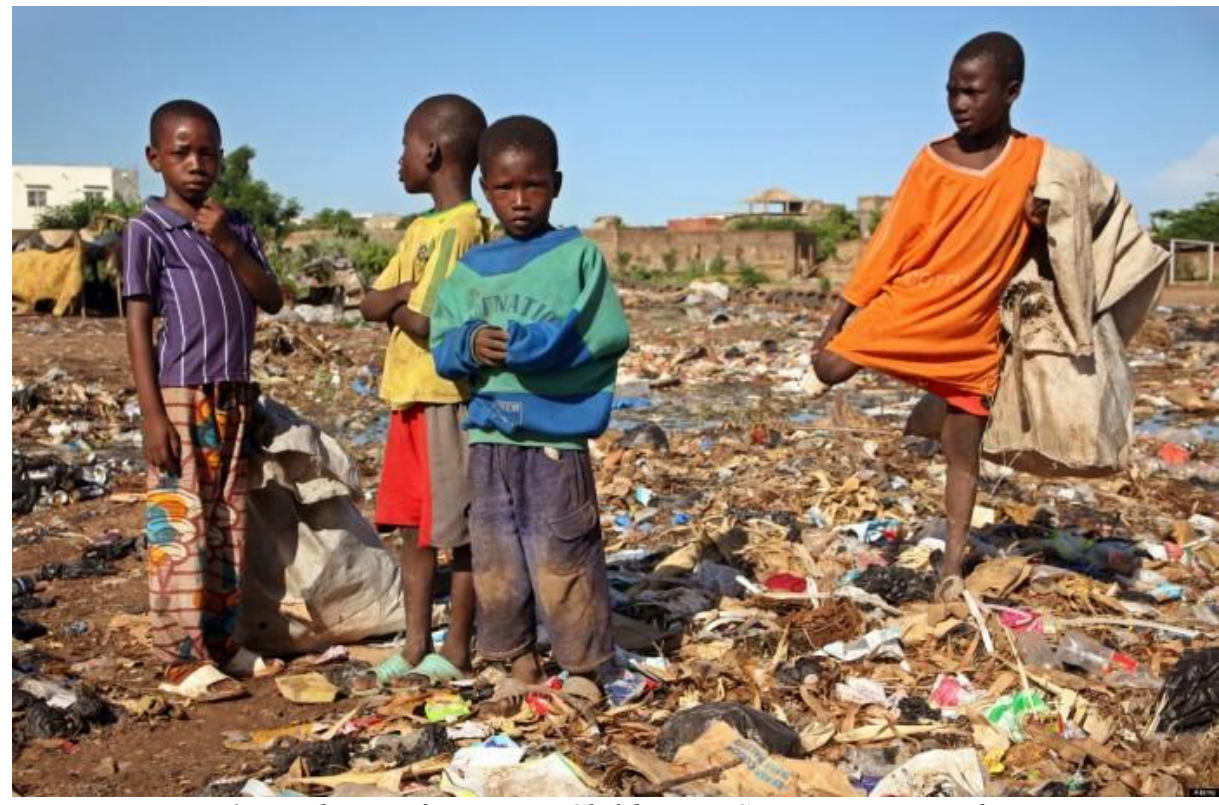

Fig. 1: Evidence of Poverty: Children as Scavengers in Refuse Dumps

(Photo: Oxfam)

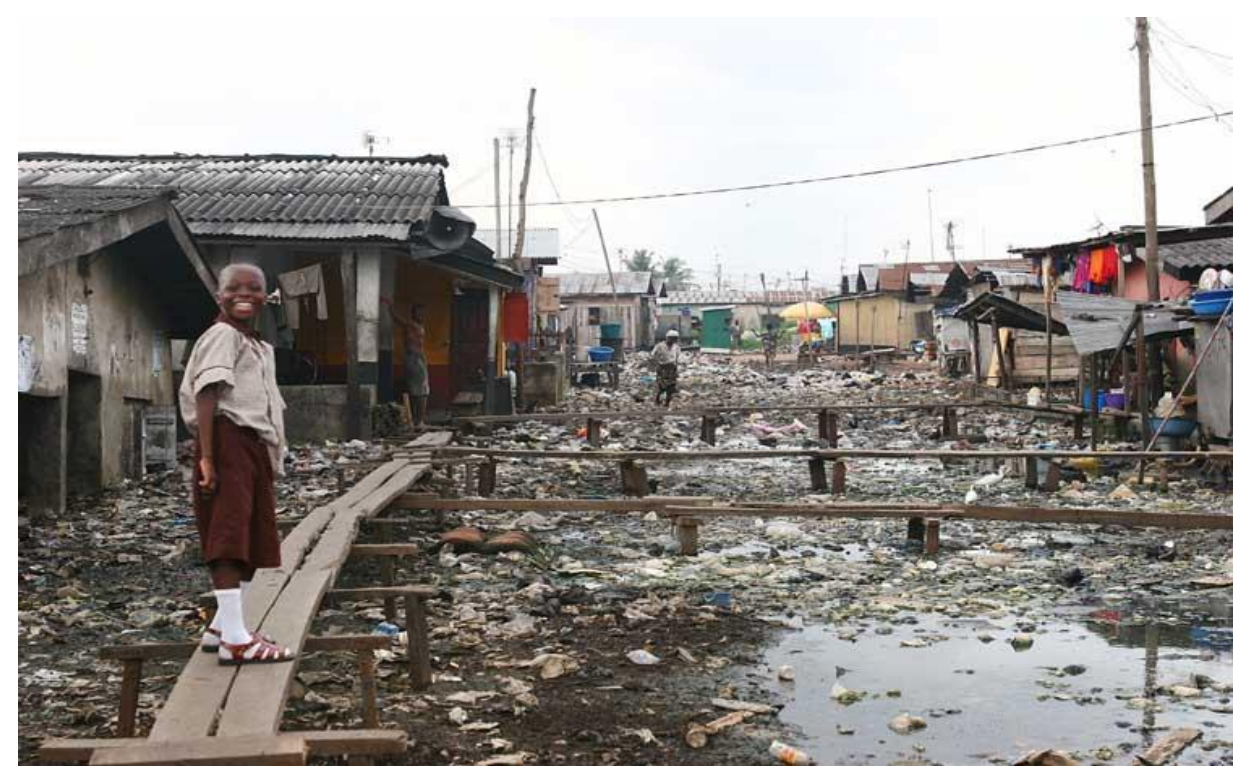

Fig. 2: Typical Slum in a Nigerian City

Agriculture is a fundamental instrument for sustainable development, poverty alleviation and enhanced food security in developing countries. In the present days, where hunger and poverty seem to be the order of the day, agriculture serves as a vital tool in eliminating the problem. In Africa including Nigeria agriculture is an effective option for spurring growth, overcoming poverty and improving food security. Therefore high agricultural productivity is essential in enhancing growth in other sectors of the economy. Agriculture remains a significant sector in Nigeria's economy despite the extensive role of the oil sector in the economy. 


\section{Objectives of the Study}

This study is broadly aimed at conducting a poverty index survey in Delta State, Nigeria

The specific objectives of the study were to:

i. determine the education index in the area by finding out;

a. The number of persons in a household that have completed at least 6 years in school,

b. The number of children in a household that have attained school age not yet attending school,

ii. $\quad$ Ascertain the health index of the study area by;

Identifying household members not having access to balance meal per day: who are malnourished,

establishing the level of child mortality through finding out if a child has died within a household 5 years prior to the survey being conducted, and

Identifying the household (people/Communities) without access to functional health facilities;

iii. Determine the standard of living index of households in the study area by finding out:

Number of persons living in a household/ household not having access to clean drinking water and improved sanitation facilities,

iv. Determine the proportion of the population in the LGAs/communities living below poverty

line (Below $\$ 2.00$ per day).

\section{Review of Literature}

\section{Concept of Poverty}

Poverty is a multidimensional, dynamic, complex, gender and location specific phenomenon (World Bank, 2000). Abumere (1998) defines the poor as those with income below the poverty line, lack access to basic services, practical contacts and other forms of support, people in isolated rural areas and the marginal urban zones where essential infrastructures are lacking. According to Ravallion (1994), Poverty can be said to exist in a given society when one or more persons do not attain a level of economic well-being deemed to constitute a reasonable minimum by the standards of that society.

The definition provided by Ravallion suggests that the concept of poverty is very much determined by the norms, values and circumstances of the society. The NBS (2011) report indicates that about 112.52 million Nigerians are living below the poverty line, this represents about 68.7 percent of the Nigerian population, despite the fact that the Nigerian economy is growing at 7 percent per annum, the proportion of Nigerians living in poverty is increasing every year and more severely aggravated. Despite various governments' effort to reduce poverty incidence through poverty alleviation programmes and strategies and the quest to be one of the 20 largest economies by the year 2020, Nigeria continues to be one of the poorest countries in the world. The Nigerian poverty rate stood at 69 percent in 2010, while 93.9 percent Nigerians considered themselves to be poor in 2010 as against 75.5 percent recorded in 2004 (NBS, 2011). 
One of the major challenges for targeting the poor lies in the spatial complexity of the problem, (the space effect on poverty transition and variation) (Ebizimor and Eluwa, 2013). Poverty variations are influenced by living in a place (geographical location, accessibility, availability of resources, and so on) and socio-cultural factors (changes in household composition, employment status, educational status, ownership of assets, human capability, remittances, health and disability status). Each of these parameters has a spatial dimension which can be explained.

Investigating poverty dynamics necessarily begins with the questions: How is poverty defined and what are the dynamics of poverty transition? The dynamic nature of poverty adds an important aspect to the analysis of poverty as some households experience poverty for long periods of time, while others only experience it on a temporary basis. Hence, according to Baulch and Hoddinott (2000) there are considerable flows into and out of poverty pool. There is a popular perception that poverty in both developing and industrialized countries is a structural, long-term phenomenon (Baulch, 1998), but the literature indicates that poverty is a temporary phenomenon with a high percentage of households shown to have moved into poverty due to temporary shocks (such as illness, loss of job, loss of household head, and so on) which could be reversed.

The 'trigger events' or spatial and socio-cultural dynamics include geographic location, space effect on poverty transition, accessibility and availability of resources, changes in household composition, employment status, educational status, ownership of assets, human capability, remittances, health and disability status. Poverty dynamics enables a better understanding of the extent of poverty transition over space and time, and a knowledge of the factors associated with movements in and out of poverty among the vulnerable groups.

Over the years, different national poverty profiles have been constructed for example (World Bank 1996, NHDR 1996 and 1998, FOS 1999) telling who the poor are, how they are, where they live, why they are poor, what socioeconomic groups they belong and their characteristics, transition dynamics experienced, and the participation of the poor themselves in activities that would 'push' or 'pull' them out of poverty is the key to poverty transition particularly, exit from poverty.

\section{Spatial Distribution and Variability of Poverty}

The poverty mapping studies conducted in Kenya, Uganda, Vietnam, Sri Lanka and several other developing countries reported spatial variability of poverty across geographic domains (Baulch and Hoddinott, 2000). According to them, the variability in spatial distribution of poverty is related to its geographic determinants such as differences in geographic and agro-climatic conditions, infrastructure, good road networks, access to market and public facilities, information technology, the presence or absence of natural resources such as forests, crude oil, natural gas, solid minerals or water bodies and socio-cultural and historical factors.

\section{Research Methodology}

Study Area Delta State is the study area. Delta State is one of the nine (9) States in the Niger Delta Region of Nigeria. The State was carved out of the former Bendel State on 27 August 1991 and has twenty five (25) local government areas (Figure 1). Delta State is ethnically diverse, with various linguistic stocks. Delta State is an oil and agricultural producing state of Nigeria, situated in the region known as the South-South geo-political zone with a population of 4,112,445 (males: 2,069,309; females: 2,043,136) (NPC, 2006). The state has a total land area of 16,842 square kilometres $(6,503 \mathrm{sq} \mathrm{mi})$ and covers a landmass of about $18,050 \mathrm{~km}^{2}$, of which more than $60 \%$ is land.

The State lies approximately between Longitude $5^{\circ} 00$ and $6^{\circ} .45^{\prime}$ East and Latitude $5^{\circ} 00$ and $6^{\circ} .30^{\prime}$ North. It is bounded in the north and west by Edo State, the east by Anambra, Imo, and Rivers States, southeast by Bayelsa State, and on the southern flank is the Bight of Benin which covers about 160 kilometres of the state's coastline. 
Delta State is generally low-lying without remarkable hills. The State has a wide coastal belt inter-lace with rivulets and streams, which form part of the Niger River Delta. The vast majority of inhabitants are Christian, with very few practicing Traditional Religion.

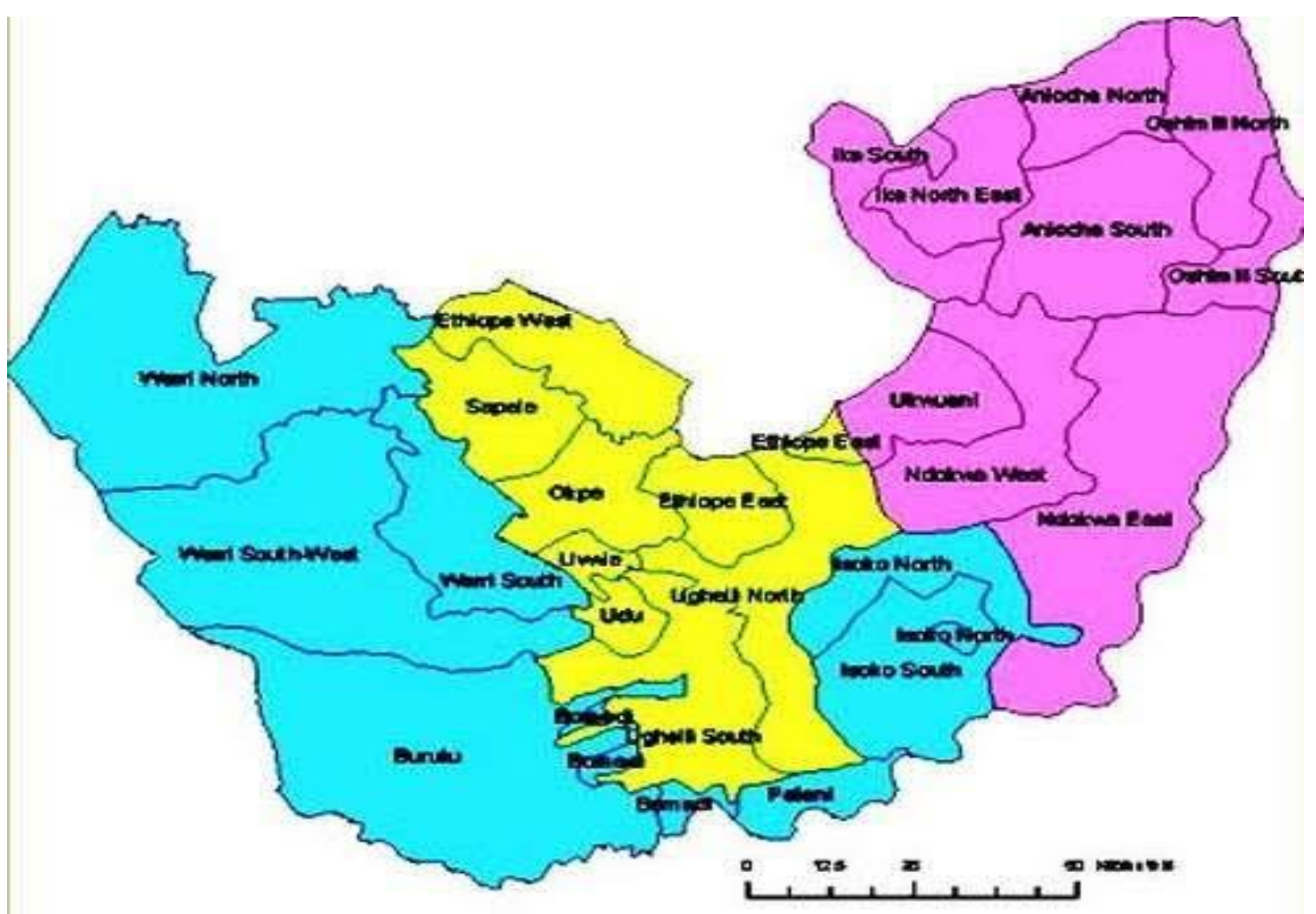

1: Map of Delta State showing the 25 Local Government Areas

Source: https://en.wikipedia.org/wiki/DeltaState

\section{Sampling Procedure}

This involved a multistage sampling procedure. In the first stage fifteen Local Government Areas (LGAs) were randomly selected from the twenty five LGAS that make up the State. In the second stage, two communities were sampled from each of the selected LGA and this gave a total of thirty communities. A random sample of fifteen households was selected from each of the thirty (30) communities. This gave a total of four hundred and fifty (450) households that were selected for the study.

\section{Data Collection}

Data for this survey were collected from primary sources through the use of a structured and pre-tested questionnaire. Trained enumerators fluent in both English language and the local languages of the areas were used for data collection. Data to be collected include quantifiable and non-quantifiable factors affecting income and household expenditure pattern. These are households' monthly income and their sources, household size, age, marital status, expenditure on various consumer items, occupation/employment and other household nonfood expenditure. The consumer items that were considered are food, accommodation, clothing, transport, electricity, education, drinks and entertainment and other goods and services. 
Other specific data collected are individual level of educational attainment in the household, number of children of school age that are out of school in the household, infant mortality on household basis as well as functional health facilities that serves the need of households among others.

\section{Methods of Data Analysis}

Descriptive statistical tools including tables, mean, percentages were applied in the analysis of data. Also inferential statistical tools such as regression analysis as well as poverty measure using Foster Greer and Thorbecke (1984) model to estimate the incidence of poverty were applied in the analysis of data.

The poverty line in the area was derived from mean per capita household expenditure (MCHE) as Per capita household expenditure $=\frac{T H M E}{H S}$

where THME is the total household monthly expenditure (N) and HS is the household size.

The mean per capita expenditure (MPCE) for all respondents was determined as the ratio of total per capita expenditure for all households to total number of households as follows:

$M P C E=\frac{T P C E}{T N H}$ where TPCE is total per capita expenditure for all households and

TNH is total number of households.

Three mutually exclusive classes obtained from the MPCE are:

i. A core poverty line equivalent to one third of MPCE.

ii. The moderate poverty line equivalent to two third of the MPCE.

iii. The non-poor

iv. The poverty incidence was measured using Foster Greer and Thorbecke (FGT) (1984) approach.

The FGT measure is given mathematically as follows:

$P_{a}=\frac{1}{n} \sum_{i=1}^{q}\left[\frac{Z-Y_{i}}{Z}\right]^{\alpha}$ where a $\geq 0, \mathrm{Yi}=$ per capita household expenditure, $\mathrm{Z}=$ poverty line

$\mathrm{n}=$ total population, $\mathrm{q}=$ number of poor people (below poverty line).

This is simply proportion of the poor to the total population (i.e. head ratio).

$P_{o}=\frac{q}{n}=H \quad$ where $\mathrm{Po}=$ Poverty Index, $\mathrm{H}=$ Head count 
This measures the depth of poverty, otherwise called poverty gap between poor household and poverty line if a

$=1 P_{a}=\frac{1}{n} \sum_{i=1}^{q}\left[\frac{Z-Y_{i}}{Z}\right]$, and if a $=2 P_{a}=\frac{1}{n} \sum_{i=1}^{q}\left[\frac{Z-Y_{i}}{Z}\right]^{2}$

\section{Analytical method for Determinants of Poverty (Use of Binary Probit Model)}

Universally chronic poverty is defined as a condition whereby the average per adult income is less than US\$1 per day. Denoting per person income (or expenditure) by X and chronic poverty line by Z, Chronic poverty (Pc) can then be expressed as:

$$
P c=\int 0^{z} \otimes(Z, X) f(X) \delta X
$$

Where $\otimes(Z, X)$ is the deprivation suffered when household's income is $X$, whereby is Zero when $X \geq Z$ (that is) when income per person is above one dollar or above chronic poverty line) and 1 otherwise. Therefore, chronic poverty is equal to (1) if average per person income in a household is less than US\$1 per day and (0) otherwise. This implies that factors with positive influence on Pc are those that increase the probability for a given household to remain below chronic poverty line, while negative factors are those that reduce the probability of a household staying below poverty line.

Currently in Nigeria, a chronic poverty is equated to income per person per day that is below $1 \$$ or N360; thus, to arrive at the dollar rate, the total household expenditure per day (an equivalent to daily full income) then divide by the number of household members. The probability estimation of these factors follows a binary probit model (Greene, 2003) as below.

$$
\operatorname{Pr} o b[D=j]=\frac{\exp \left(\beta_{1} X_{j}\right)}{S(j=0-j)-\exp \left(\beta_{1} X_{1}\right)^{j=0,1 \ldots . . . j}}
$$

Where $\mathrm{Xi}$ is a vector of covariates that define household characteristics, with the log likelihood function expressed as:

$$
r\left(D_{1}=1\right)=\frac{1}{1+\sum_{j=1}^{j} \exp \left(\beta_{1} X_{1}\right)}
$$

In its reduced form, the model becomes

$$
D(0,1)=\frac{P}{\log (1-P)}=\beta_{0}+\beta_{i j} X_{i j}+\varepsilon
$$

Where, D is the indicator for a household falling below chronic poverty line, $\mathrm{P}$ is the probability of event's occurrence, while $\mathrm{Xi}$ is a vector of household socioeconomic characteristics, covering household specific factors such as age, education, household size, ownership of title to land, access to transfers, non-farm employment, market characteristics such as distance to the markets, credit markets and community based factors such as group memberships. $\beta 0$ and $\beta 1$ are the corresponding vectors of parameters and $\varepsilon$ is the disturbance term. Similar analytical methodology has been employed by (Adeoti and Adewusi, 2005; Owuor, 2007). 


\section{Variables and hypothesized effects}

The dependent variable was dummy with those households living below a dollar per day per person represented with (1) implying that the household is chronically poor and 0 otherwise. Thus, factors that negatively influence the dependent variable are those that reduce poverty, while those with positive effects increase prevalence of poverty.

The explanatory variables with their hypothesized effects on chronic poverty are presented in Table 3.2. These are:

Access to credit which is theoretically expected to reduce poverty through cash investment in productive activities and also smoothing consumption.

Age of household head which is perceived to be less productive and consequently the household is expected to be chronically poor.

Access to education as well as exposure to agricultural workshops was also hypothesized to reduce chronic poverty, implying that the more educated the decision maker the better skilled and productive he or she is and consequently experiences less poverty.

Female involvement in decision making was hypothesized to have either positive or negative effects on chronic poverty. Traditionally, no theoretical foundations exist on gender and poverty. Nonetheless, in Africa more women than men are involved in rural economic activities such as farming. However, at the same time majority of women in Africa have no rights to property, a factor that infringes on their access to either input or credit markets which drags their households towards poverty.

Landholding size on the other hand releases the binding of land constraint for all sorts of enterprises and is also an asset which enables households to easily access both input and credit markets. Literature on land ownership indicates that land enhances the chances of diversification into varieties of enterprises and thus, improves the overall farm profitability and reduces poverty levels.

Constant access to remittances, livestock assets and engagement in non-farm activities presents households with additional income for productive investment and/or consumption smoothing - which are expected to have a negative impact on chronic poverty.

Experienced farmers that readily have access to government programmes such as SEEFOR/FADAMA III interventions and/or other government schemes are hypothesized to perform better in agricultural production resulting into lowering poverty levels compared with their counterparts that are not benefiting.

However, with respect to Farms located at a greater distance from inputs and outputs markets are expected to be poorer than those located nearer to the markets due mainly to the high transactions costs that infringe on their farm incomes.

Also households with large sizes are expected to positively influence chronic poverty. This is because with fixed income the resources of the household are stretched over a large number of people. 
Table 1: Variables with their Hypothesized Effects

\begin{tabular}{lll}
\hline Variables & Definition & $\begin{array}{l}\text { Hypothesized } \\
\text { effect on poverty }\end{array}$ \\
\hline Access on MFB credit & Access on MFB credit & $(+)$ \\
Access to other credit & If access other credit (Yes, No) & $(+)$ \\
Age of head & Age of decision makers in years & $(+,-)$ \\
Education of head & Formal education in years of decision makers & $(-)$ \\
Seminars attendance & If attended agric-seminar last year (Yes, No) & $(-)$ \\
Sex of household head & If decision maker is female (Yes, No) & $(-)$ \\
Ownership of land title & If owns title to farm land (Yes, No) & $(-)$ \\
Remittances & Has access to constant remittances (Yes, No) & $(-)$ \\
Hours spent on non-farm activity & Hours spent daily on non-farm activity (hours) & $(-)$ \\
Belonging to cooperative & If member of self-help group (Yes, No) & $(+,-)$ \\
Distance to market & Distance to the local market (Kilometres) & $(+)$ \\
Value of livestock assets & Value of livestock seeds (Naira) & $(-)$ \\
Access to extension & If access to extension services & $(-)$ \\
Family size & If family size is so large & $(+)$ \\
\hline
\end{tabular}

\section{Results and Discussion}

\section{Determination of Education Index}

The level of educational attainment by indigenes and/or residents of a community have a significant effect on their development. Education is a key to development and wellbeing of persons and households. It is a vital component of measuring poverty.

The level of educational attainment and child enrollment are regarded in this study as indicators for determining households that are educationally deprived.

\section{Formal Primary School Education}

A household is considered deprived, if no one in the household has formal education of 6 years among those who are old enough to have achieved 6 years of education. That is, anyone of age 13+ should hypothetically have $6+$ years of education. On the other hand, if all or just one member of the household has attained 6 years of formal education among those who are old enough to have achieved 6 years of education, that household is not educationally deprived.

Findings from the study as depicted in Table 2 shows that about $2.63 \%$ of the respondent households are educationally deprived. By implication, the percentage of educationally deprived households in the communities surveyed and by extension, Delta State is low. This finding is in tandem with the earlier report of Delta State 2015 Poverty Mapping and Social Exclusion Survey which established that Delta State has a low percentage of households that are educationally deprived. Hence, Delta State is not among the educationally disadvantaged States in Nigeria. 
Table 2: Percentage Distribution of Households on LGA basis in terms of Educational Deprivation

\begin{tabular}{llll}
\hline & & DEPRIVATION & NOT DEPRIVED \\
\cline { 3 - 4 } S/N & Local Government Area & DEPRIVED & 98.55 \\
\hline 1 & Aniocha South & 1.45 & 97.95 \\
2 & Etiope East & 2.05 & 97.12 \\
3 & Ethiope West & 2.88 & 96.06 \\
4 & Ika North East & 3.94 & 96.04 \\
5 & Ika South & 3.96 & 99.27 \\
6 & Isoko North & 0.73 & 97.29 \\
7 & Isoko South & 2.71 & 91.36 \\
8 & Ndokwa East & 8.64 & 98.18 \\
9 & Ndokwa West & 1.82 & 95.82 \\
10 & Okpe & 4.18 & 99.13 \\
11 & Oshimil North & 0.87 & 99.08 \\
12 & Oshimili South & 0.92 & 98.22 \\
13 & Sapele & 1.78 & 98.31 \\
14 & Ughelli North & 1.69 & 98.24 \\
15 & Ughelli South & 1.76 & 97.37 \\
& State Average & 2.63 & \\
\hline
\end{tabular}

However it can be observed that communities in six (6) Local government areas have above average value of $2.63 \%$ in terms of educational deprivation. These are Isoko South $(2.71 \%)$, Ethiope West $(2.88 \%)$, Ika North East (3.94\%), Ika South (3.96\%), Okpe (4.18) and Ndokwa East (8.64\%) households were educationally deprived.

A gender analysis further reveals that females topped the list in all communities as those that are educationally deprived. In most of the deprived communities, over $70 \%$ of women, particularly the elderly women are deprived. Isoko South, Ethiope West, Ika North East and Ika South were moderately deprived while Okpe and Ndokwa East LGAs were in the extreme of the deprivation.

Following the findings of this survey it is important to note that even though Delta State has done well in educational advancement of its citizens, more efforts has to be directed towards achieving education for all and in particular, to intervene in those LGAs higher than $2.63 \%$ State level to forestall further escalation. Also there is the need for government to set up educational programmes for adult literacy in various communities in the State. This will help illiterate youths and the elderly to achieve $100 \%$ literacy in the State.

\section{Child Enrollment in Schools}

Another way of assessing households that were educationally deprived is by looking at school attendance for children between $1-8$ years.

A household is considered deprived if at least one child of age between $1-8$ years never attended school or attended in the past but not now or do not have 6 years of education.

Result in Table 3 shows the percentage distribution of children aged $1-8$ years and enrollment status on local government basis. The result indicates that on the average $6.48 \%$ of children aged between $1-8$ years in the study area never attended school while $2.24 \%$ attended in the past but not now. 
In this survey, children aged 1- 8 years who have never attended school or who have attended in the past but not now were considered educationally deprived. Thus, $8.72 \%$ of children aged 1-8 years in the study area are educationally deprived.

As shown in the table, six (6) local government areas had higher child deprivation index compared to the State index of $8.72 \%$. These LGAs are Aniocha South, Ethiope West, Ika North East, Ndokwa East, Ndokwa West and Oshimili North.

A number of reasons were found to be behind deprivation of educational enrollment of children in schools in the communities. Among these are finance, child abuse in the form of child labour, child trafficking, marketing of sachet water, roasted maize and general hawking of wares along the roads or the streets instead of being in school.

Hence there is the need for the intervention of the State through enforcement of compulsory child enrollment in schools in all parts of the State.

Table 3: Percentage Distribution of Children: LGA by Age $(1-8)$ and Enrolment Status

\begin{tabular}{|c|c|c|c|c|}
\hline \multirow[b]{2}{*}{$\mathrm{S} / \mathrm{N}$} & \multirow[b]{2}{*}{ Local Government Area } & \multicolumn{3}{|c|}{ AGE $1-8$} \\
\hline & & Never Attended & $\begin{array}{l}\text { Attended in the Past } \\
\text { but not now }\end{array}$ & $\begin{array}{l}\text { Attending Primary } \\
\text { School }\end{array}$ \\
\hline 1 & Aniocha South & 8.77 & 2.87 & 88.36 \\
\hline 2 & Etiope East & 4.51 & 0.92 & 94.57 \\
\hline 3 & Ethiope West & 7.15 & 7.63 & 85.22 \\
\hline 4 & Ika North East & 9.92 & 0.65 & 89.43 \\
\hline 5 & Ika South & 5.23 & 1.02 & 93.75 \\
\hline 6 & Isoko North & 5.52 & 0.72 & 93.76 \\
\hline 7 & Isoko South & 4.03 & 3.05 & 92.92 \\
\hline 8 & Ndokwa East & 8.98 & 5.46 & 85.56 \\
\hline 9 & Ndokwa West & 10.17 & 0.62 & 89.21 \\
\hline 10 & Okpe & 4.31 & 0.61 & 95.08 \\
\hline 11 & Oshimil North & 9.53 & 2.09 & 88.38 \\
\hline 12 & Oshimili South & 4.35 & 0.92 & 94.73 \\
\hline 13 & Sapele & 5.44 & 0.55 & 94.01 \\
\hline 14 & Ughelli North & 4.25 & 4.20 & 91.55 \\
\hline \multirow[t]{2}{*}{15} & Ughelli South & 5.05 & 2.28 & 92.67 \\
\hline & State Average & 6.48 & 2.24 & 91.28 \\
\hline
\end{tabular}

\section{Determination of Health Index}

According to the World Health Organization, Health is a complete physical, mental and social wellbeing and not merely the absence of diseases or infirmity (Grad, 2002). Health is a dynamic condition resulting from a body's constant adjustment and adaptation in response to stresses and changes in the environment for maintaining an inner equilibrium called homeostasis.

Health is one of the key indicators used in determining multidimensional poverty index. 


\section{Nutrition:- Access to Balanced Meal per day}

Eating right and engaging in regular physical activity are decisions all individuals can make to lower the risk of health problems. However, the choices made by children and adolescents are strongly affected by the family and community environments in which they live.

This survey sought to know from households if their children usually have;

$\checkmark$ Three meals a day

- A meat/fish meal at least twice a day.

The findings from the respondent households who have children living with them as shown in Table 4 indicate that over $27 \%$ of children in the State do not take three meals a day. It is worrisome that 8 Local government areas have higher percentage than the State average in the number of children who do not take standard number of meals in a day. Ika south tops the list with $72.41 \%$ followed by Ethiope East (49.78\%), Ughelli North (42.62\%) and Ndokwa West (41.05\%) amongst others. The implication of skipping meals by children is of high consequence as it can lead to many health problems as well as poor brain development.

Table 4: Percentage Distribution of Household by Children Nutritional level

\begin{tabular}{|l|l|l|l|l|l|}
\hline \multirow{2}{*}{ S/N } & & \multicolumn{2}{l|}{ Have three meal a day } & \multicolumn{2}{l|}{ Have meat/fish at least twice a day } \\
\cline { 3 - 6 } & & Les & No & Yes & No \\
\hline 1 & Aniocha South & & & & \\
2 & Etiope East & 87.64 & 12.36 & 20.99 & 79.01 \\
3 & Ethiope West & 50.22 & 49.78 & 48.70 & 51.30 \\
4 & Ika North East & 68.22 & 31.78 & 42.72 & 57.28 \\
5 & Ika South & 88.37 & 11.63 & 72.09 & 27.91 \\
6 & Isoko North & 27.59 & 72.41 & 65.52 & 34.48 \\
7 & Isoko South & 88.46 & 11.54 & 84.97 & 15.03 \\
8 & Ndokwa East & 68.35 & 31.65 & 29.80 & 70.20 \\
9 & Ndokwa West & 76.60 & 23.40 & 53.19 & 46.81 \\
10 & Okpe & 58.95 & 41.05 & 48.96 & 51.04 \\
11 & Oshimil North & 60.90 & 39.10 & 36.84 & 63.16 \\
12 & Oshimili South & 89.47 & 10.53 & 61.84 & 38.16 \\
13 & Sapele & 70.90 & 29.10 & 49.62 & 50.38 \\
14 & Ughelli North & 96.50 & 3.50 & 88.00 & 12.00 \\
15 & Ughelli South & 57.38 & 42.62 & 48.85 & 51.15 \\
& State Average & 96.84 & 3.16 & 62.66 & 37.34 \\
\hline
\end{tabular}

\section{Taking of meat/fish meal at least twice a day}

Findings of the level of consumption of meat/fish by children at least twice a day in their meals indicate that more than $45 \%$ of children in households studied do not consume meat/fish for at least twice daily (Figure 2). Nine LGAs have above State index of $45.68 \%$ in non-consumption of meat/fish twice daily in their meals by children. Top of the group is Aniocha South followed by Isoko South, Okpe among others. 
Ubulu Uku community in Aniocha South and Ovowodokpo Igide in Isoko South as well as Okuloho in Okpe LGAs presents cases that are more than the State average.

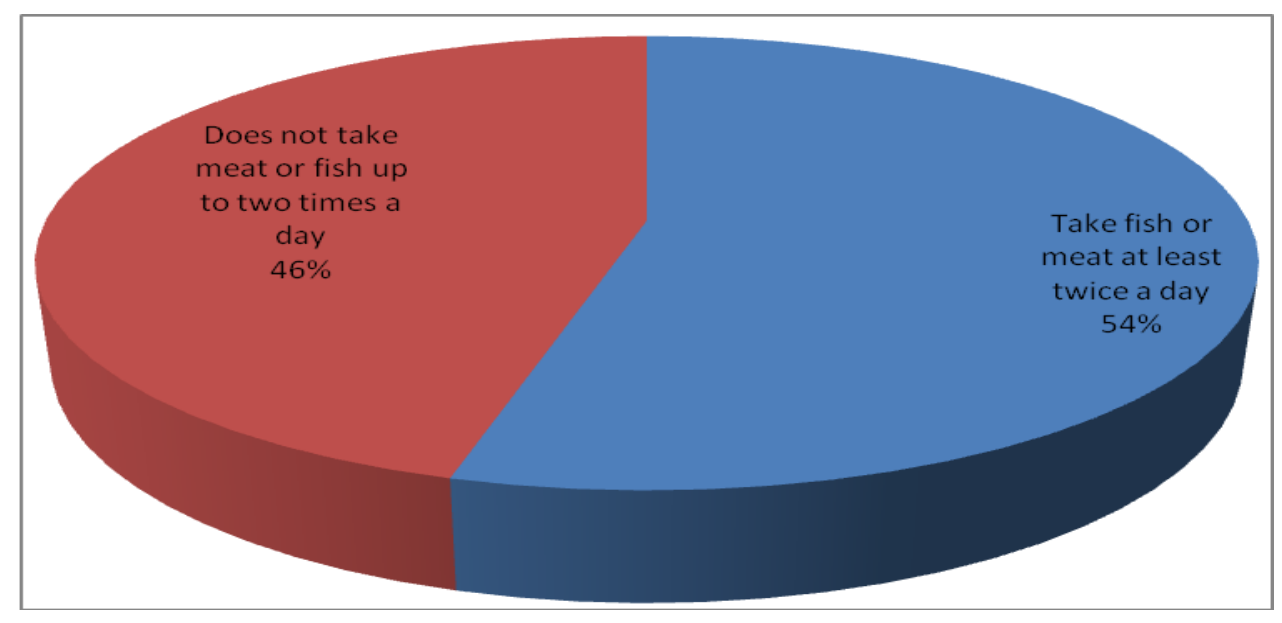

Fig. 2: Pie Chart on level of consumption of meat/fish

\section{Feeding Habit of Adult Members of Households}

The feeding habits of other members of households apart from children were also surveyed in this study. This was done by finding out whether adult members of the household deliberately hold back on food so that others in the household can have enough to eat. The adequacy of the quality and quantity of meat/fish bought for household consumption was also sought for in the survey. Findings indicated that over $80 \%$ of the respondent households do buy cheaper cuts of meat or less than what they would like to buy. The implication of this finding is a reduce rate of animal poultry consumption per day as against the minimum standard of $65 \mathrm{mg}$ set by World Health Organization.

\section{Child Mortality}

The distribution of infant mortality across the Communities/Local government areas under study indicates a low level of child mortality with an average of 1.7 infant deaths in the State in the last five years (Table 5). This translates to a total of $17 / 1000$ deaths. The ages of those that died ranged form few months after birth to early adulthood of 21 and 23 years.

This finding compares favourably with data on Delta State infant mortality over the years (UNDP, 2015) which were given as 48/1,000 live births (2003), 32.3/1,000 live births (2006), 32.3/1,000 live births (2011) and 37 per 1,000 live births (2012). The national baseline value (1990) is 91/1,000 live births while the target for this indicator is 30.3 per cent by 2015 .

Table 5: Distribution of Child Mortality among Households

\begin{tabular}{lll} 
S/N & Local Government Area & Number of Mortality in the last 5 Years \\
1 & Aniocha South & 2 \\
2 & Etiope East & 0 \\
3 & Ethiope West & 2 \\
4 & Ika North East & 1 \\
\hline
\end{tabular}




\begin{tabular}{lll}
\hline 5 & Ika South & 1 \\
6 & Isoko North & 1 \\
7 & Isoko South & 4 \\
8 & Ndokwa East & 4 \\
9 & Ndokwa West & 0 \\
10 & Okpe & 0 \\
11 & Oshimil North & 3 \\
12 & Oshimili South & 4 \\
13 & Sapele & 1 \\
14 & Ughelli North & 2 \\
15 & Ughelli South & 1 \\
& State Average & 1.73 \\
\hline
\end{tabular}

\section{Under-5 mortality rate}

According to UNDP (2015) which documented the Delta State health sector report 1991 - 2013, gave the under 5 mortality rate as: 102 per 1,000 live births (2003), 54.4 per 1,000 live births (2006), 108 per 1,000 live births (2011) and 52 per 1,000 live births (2012). The national baseline value (1990) is 191/1,000 live births while target for is 63.7 per cent by 2015 .

\section{Household Health Performance and Access to Functional Health Facilities}

\section{Household Health Assessment}

The status of the respondent households with respect to assessment of their health status in the last 12 months was sought. This was to establish if personal health status has been excellent, good, fair or poor in the last 12 months. The findings are as presented in Table 6.

From the findings it is shown that over $9 \%$ of the respondent households indicated that they are in poor health. This is worrisome when taken into consideration with the population of the entire State. With the State population given as 5.4million in 2006 population census and an estimated growth rate of $3.18 \%$, it implies that over 500,000 indigenes of the State are not in good health.

On the other hand it also means that over $90 \%$ of households in the State believe that they are healthy.

Table 6: Percentage Distribution of Households on Health Status in the Last 12 Months

\begin{tabular}{llllll}
\hline S/N & Local Government Area & Excellent & Good & Fair & Poor \\
\hline 1 & Aniocha South & 18 & 56 & 8 & 18 \\
2 & Etiope East & 26 & 28 & 32 & 14 \\
3 & Ethiope West & 2 & 76 & 20 & 2 \\
4 & Ika North East & 1 & 70 & 23 & 6 \\
5 & Ika South & 1 & 27 & 46 & 26 \\
6 & Isoko North & 1 & 83 & 14 & 2 \\
7 & Isoko South & 20 & 48 & 19 & 13 \\
8 & Ndokwa East & 1 & 59 & 36 & 4 \\
9 & Ndokwa West & 4 & 68 & 22 & 6 \\
\hline
\end{tabular}




\begin{tabular}{llllll}
\hline 10 & Okpe & 1 & 45 & 38 & 16 \\
11 & Oshimil North & 1 & 51 & 41 & 7 \\
12 & Oshimili South & 8 & 43 & 43 & 6 \\
13 & Sapele & 5 & 73 & 19 & 3 \\
14 & Ughelli North & 2 & 61 & 21 & 16 \\
15 & Ughelli South & 36 & 52 & 9 & 3 \\
& State Average & 8.47 & 56.00 & 26.07 & 9.46 \\
\hline
\end{tabular}

It is important to note that across local government areas, Ika South, Aniocha South, Okpe, Ughelli North, Ethiope East and Isoko South have higher than the average State index of households with poor health. Any health intervention should focus on these LGAs as priority areas.

\section{Standard of Living Index of Households}

The standard of living is defined as how well or how poorly a person or household live in terms of meeting their basic needs and wants. It is also the level of wealth, comfort, material goods and necessities available to the person or household, i.e. the state of welfare. Standard of living is a combination of many factors that are generally believed to enhance the quality of life of individuals or group of persons. Improving the standard of living is the main reason why plans and programmes are put in place.

Inequality in standard of living is a growing social problem. Hence this survey has become very necessary for development agencies in the State such as FADAMA III and SEEFOR as well as State ministries of Economic Planning, Women Development and Poverty Alleviation, amongst to understand the economic matrices of poverty in Delta State.

The standard of living index of households in this survey was estimated using different parameters. Among these are: Number of Persons living in a Household, access to Electricity, access to clean drinking water, access to improved sanitation facilities, access to at least one asset related to information for example, radio, television, telephone, internet facilities etc. and access to assets related to mobility for example Motor Cycle, Car, Truck, Animal Cart or Motor Boat.

\section{Household Accommodation and Number of Persons Living in a Household}

Shelter (Accommodation) like food is one of the most important basic necessities of any human being. The type of accommodation in which a household lives partly determines the level of poverty or affluence of that household. It is one indicator for measuring poverty.

In this survey, as is the standard practice, households living in traditional structure, squatting or living in an improvised/informal dwelling is considered to be deprived (poor). Also, a household is considered deprived if there is no privacy amongst members because they live in an accommodation that does not have enough rooms. The distribution of households by the type of accommodation is presented in Table 7.

The findings as shown in the table reveal that 5.99\% (about 6 in every 100) households in the study area live in traditional hut structure while $4.21 \%$ live in informal or improvised dwellings. These two types of accommodation constituting $10.2 \%$ of the total households surveyed are considered deprived (living in poverty). The implication of this finding is that one in every 10 households in the area live under poor housing structure with the situation more pronounced in the rural and riverine areas of the State. 
At the local government level, more households live in traditional hut structure in Ethiope East (21.54\%), Ndokwa East (15.08\%), Oshimili South (10.22\%), Isoko South (9.72\%) and Ughelli North 8.08\%). Ndokwa East with $17.46 \%$ recorded the highest number of households dwelling in informal/improvised houses.

Table 7: Percentage Distribution of Households by Type of Accommodation

\begin{tabular}{|c|c|c|c|c|c|c|c|c|c|}
\hline \multirow[b]{2}{*}{$\mathrm{S} / \mathrm{N}$} & \multirow[b]{2}{*}{ LG A } & \multicolumn{8}{|c|}{ Type of Accommodation } \\
\hline & & $\begin{array}{l}\text { Detache } \\
\text { d house/ } \\
\text { bungalo } \\
\text { w }\end{array}$ & $\begin{array}{l}\text { Semi } \\
\text { Detached } \\
\text { house/ } \\
\text { bungalow }\end{array}$ & $\begin{array}{l}\text { Block } \\
\text { of } \\
\text { Flats }\end{array}$ & $\begin{array}{l}\text { Dwelling } \\
\text { with } \\
\text { Business } \\
\text { premises }\end{array}$ & $\begin{array}{l}\text { Bed } \\
\text { Sitter }\end{array}$ & $\begin{array}{l}\text { Room } \\
\text { s to } \\
\text { let }\end{array}$ & $\begin{array}{l}\text { Informal/ } \\
\text { Improvise } \\
\text { d dwelling }\end{array}$ & $\begin{array}{l}\text { Traditiona } \\
1 \text { Hut } \\
\text { Structure }\end{array}$ \\
\hline 1 & Aniocha South & 19.84 & 2.38 & 15.08 & 3.97 & 11.11 & 35.71 & 11.90 & $0-00$ \\
\hline 2 & Etiope East & 14.63 & 5.28 & 31.30 & 0.41 & 5.61 & 20.23 & 0.81 & 21.54 \\
\hline 3 & Ethiope West & 2.03 & 3.25 & 49.19 & 0.41 & 3.66 & 39.84 & 0.00 & 1.63 \\
\hline 4 & Ika North East & 7.17 & 10.31 & 43.95 & 0.90 & 1.79 & 32.74 & 2.69 & 0.45 \\
\hline 5 & Ika South & 41.18 & 6.86 & 15.69 & 1.96 & 0.98 & 29.41 & 3.92 & 0.00 \\
\hline 6 & Isoko North & 1.14 & 0.00 & 13.14 & 10.29 & 6.86 & 60.00 & 3.43 & 5.14 \\
\hline 7 & Isoko South & 3.47 & 5.21 & 34.03 & 2.78 & 10.42 & 32.64 & 1.74 & 9.72 \\
\hline 8 & Ndokwa East & 17.46 & 20.63 & 11.90 & 8.73 & 3.17 & 5.56 & 17.46 & 15.08 \\
\hline 9 & Ndokwa West & 9.29 & 19.13 & 51.91 & 0.55 & 6.01 & 2.73 & 4.37 & 6.01 \\
\hline 10 & Okpe & 3.25 & 1.95 & 17.53 & 1.30 & 5.84 & 61.04 & 2.60 & 6.49 \\
\hline 11 & Oshimil North & 2.78 & 6.25 & 45.83 & 8.33 & 5.56 & 25.69 & 0.00 & 5.56 \\
\hline 12 & Oshimili South & 10.22 & 5.91 & 32.26 & 0.00 & 9.68 & 18.82 & 12.90 & 10.22 \\
\hline 13 & Sapele & 5.56 & 18.06 & 40.74 & 1.39 & 5.09 & 29.17 & 0.00 & 0.00 \\
\hline 14 & Ughelli North & 2.78 & 13.38 & 32.32 & 2.53 & 5.30 & 34.34 & 1.26 & 8.08 \\
\hline \multirow[t]{2}{*}{15} & Ughelli South & 6.20 & 8.14 & 23.64 & 15.50 & 2.33 & 44.19 & 0.00 & 0.00 \\
\hline & State Average & 9.82 & 8.44 & 30.57 & 3.94 & 5.56 & 31.47 & 4.21 & 5.99 \\
\hline
\end{tabular}

\section{Number of Rooms Occupied by Household}

The number of rooms occupied by a household is a function of the household's level of income. It is an important element in considering poverty. Rooms occupied by households include palours and dinning but excludes kitchens, bathrooms and any room(s) that is let or sublet to another person/household. Findings of this survey as presented in Figure 3 shows that about $18.86 \%$ households in the study area live in one room and thus are considered poor and deprived. 


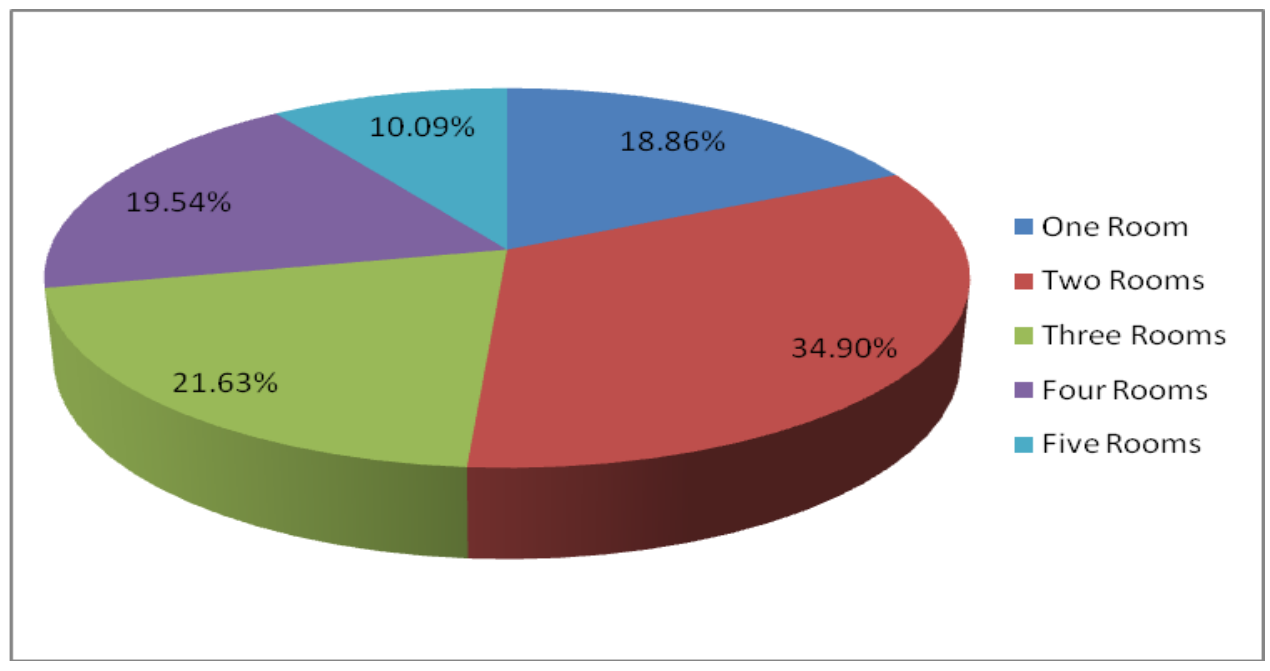

Fig. 3: Pie chart showing Distribution of Number of Rooms occupied by Households

\section{Household Access to Drinking Water, Sanitation Facilities and Electricity}

\section{Access to Drinking Water}

The household access to infrastructure such as clean water, waste disposal and electricity is another indicator that has been used in this study to examine the poverty level in the study area. More than $80 \%$ of the respondents across the 15 LGAs in the study area had access to water. However, the situation is different when looking at access to clean and safe water. Less than $60 \%(56.83 \%)$ had access to safe water on the average in the State. As it is well known, unsafe water is a major source of killer diseases (water borne diseases) such as cholera. This type of disease is more prevalent in poor and deprived environment. Inadequacy of safe drinking water is more prevalent among households in Isoko North (61.16\%), Okpe (50.44\%) and Ndokwa East $(45.33 \%)$ (Table 8$)$.

Communities including Okuloho in Okpe LGA as well as Ase-Ebeneze and Umuti in Ndokwa East LGA have higher rates of unsafe drinking water than others.

Table 8: Percentage Distribution of Household on Access to Drinking Water, Sanitation Facilities and Electricity

\begin{tabular}{llllllll}
\hline \multirow{2}{*}{ S/N } & \multirow{2}{*}{ Local Government Area } & \multicolumn{2}{l}{$\begin{array}{l}\text { Access to Drinking } \\
\text { Water }\end{array}$} & \multicolumn{2}{l}{$\begin{array}{l}\text { Access to Sanitation } \\
\text { Facilities }\end{array}$} & \multicolumn{2}{l}{$\begin{array}{l}\text { Access to } \\
\text { Electricity }\end{array}$} \\
\cline { 3 - 8 } & & Yes & No & Yes & No & Yes & No \\
\hline 1 & Aniocha South & 57.90 & 42.10 & 34.76 & 65.24 & 67.78 & 32.22 \\
2 & Etiope East & 61.21 & 38.79 & 46.98 & 53.02 & 65.33 & 34.67 \\
3 & Ethiope West & 57.73 & 42.27 & 35.89 & 64.11 & 67.77 & 32.23 \\
4 & Ika North East & 56.34 & 43.66 & 43.67 & 56.33 & 56.34 & 43.66 \\
5 & Ika South & 65.34 & 34.66 & 55.23 & 44.77 & 65.43 & 34.57 \\
6 & Isoko North & 75.68 & 24.32 & 29.78 & 70.22 & 48.90 & 51.10 \\
7 & Isoko South & 38.84 & 61.16 & 43.11 & 56.89 & 51.23 & 48.77 \\
8 & Ndokwa East & 54.67 & 45.33 & 32.54 & 67.46 & 59.87 & 40.13 \\
9 & Ndokwa West & 64.23 & 35.77 & 56.87 & 43.13 & 45.98 & 54.02 \\
10 & Okpe & 49.56 & 50.44 & 45.64 & 54.36 & 58.34 & 41.66 \\
11 & Oshimil North & 54.89 & 45.11 & 64.24 & 35.76 & 76.78 & 23.22
\end{tabular}




\begin{tabular}{llllllll}
12 & Oshimili South & 78.57 & 21.43 & 67.56 & 32.44 & 89.70 & 10.3 \\
13 & Sapele & 67.91 & 32.09 & 71.00 & 29.00 & 78.34 & 21.66 \\
14 & Ughelli North & 67.83 & 32.17 & 46.23 & 53.77 & 63.21 & 36.79 \\
15 & Ughelli South & 59.46 & 40.54 & 41.22 & 58.78 & 69.45 & 30.55 \\
& State Average & 56.83 & 43.17 & 47.65 & 52.35 & 64.30 & 35.70 \\
\hline
\end{tabular}

\section{Access to Improved Sanitation}

An improved sanitation facility is defined as one that hygienically separates human excreta from human contact. Improved sanitation includes the following kind of toilets: Flush toilet, Connection to a piped sewer system, Connection to a septic system, Flush / pour-flush to a pit latrine, Pit latrine with slab, Ventilated improved pit latrine (abbreviated as VIP latrine), Composting toilet.

The type of sanitation facilities available to a household is an indication of level of deprivation or otherwise. Poor households are prone to the use of unimproved sanitary conditions.

Sanitation facilities that are not considered as "improved" (also called "unimproved") are: Public or shared latrine (meaning a toilet that is used by more than one household), Flush/pour flush to elsewhere (not into a pit, septic tank, or sewer), Pit latrine without slab, Bucket latrines, Hanging toilet / latrine, No facilities / bush / field (open defecation).

Findings from the survey as presented in Table 8 indicate that on the average, only $47.65 \%$ of the entire respondents use improved sanitary facilities in their households leaving $52.35 \%$ as those that use unimproved sanitation. This situation portends a lot of danger because of the attendant health implications. Communities that use mostly unimproved sanitation facilities are predominant in Isoko North (70.22\%), Ndokwa East (67.46\%), Aniocha South (65.24\%), Ethiope West (64.11\%) among others (Table 9).

\section{Access to Electricity}

\section{Access to electricity, rural (\% of rural population)}

Definition: Access to electricity, rural is the percentage of rural population with access to electricity. According to World Bank, Sustainable Energy for All (SE4ALL) database, Nigeria is the second largest country in the world after India and the first in Sub-Saharan Africa with more of her population without electricity. Access to electricity, rural (\% of rural population) in Nigeria was 39.30 as of 2014 . Its highest value over the past 24 years was 39.30 in 2014, while its lowest value was 8.60 in 1990. This is as a result of Nigeria's inability to provide electricity to about 80 million of its people, according to the Bank, in a draft report of its environment and social systems assessment (ESSA) of the Power Sector Recovery Program (PSRP) it is working on with the country's federal government.

In this regard, the World Bank revealed that the country would need to connect between 500,000 to 800,000 new households to electricity sources every year between now and 2030 to be able to achieve her targets of universal access to electricity for its citizens.

Up to 83.6 percent of the urban population had access while only 39.1 percent of the rural population did. Similarly, the connection rate ranges from 26.7 percent in the northeast to 82.4 percent in the south-south zone.

Delta State, located in the south-south zone has an average access of 64.30 percent of electricity as shown in Table 8. 


\section{Household Income and Establishment of Poverty Line}

\section{Household Annual Income}

The total annual income of the sampled respondents ranged from less than N100,000.00 to N700,000.00. This translates to a monthly income of between less than N8,333.33 to N58,333.33. This further translates to a daily income of between N277.78 to N861.11. With the current Average Exchange Rate of N360 to \$1, it implies that the daily income of the respondents ranges from $\$ 0.77$ to $\$ 2.39$. The annual income range of the respondents across the State is as presented in Table 9.

Table 9: Distribution of Annual Income of Respondents across the State

\begin{tabular}{lll}
\hline Annual Income Range & Frequency & Percentage \\
\hline $100,000.00$ or Less & 130 & 32.50 \\
$101,000-200,000$ & 70 & 17.50 \\
$201,000-300,000$ & 60 & 15.00 \\
$301,000-400,000$ & 40 & 10.00 \\
$401,000-500,000$ & 30 & 7.50 \\
$501,000-600,000$ & 20 & 5.00 \\
$601,000-700,000$ & 10 & 2.50 \\
Above 700,000 & 0 & 0.00 \\
\hline
\end{tabular}

\section{Sources of Income for Respondents}

The measurement of income and its sources poses a major problem in Nigeria due to the reluctance of households to give accurate information on their income and its sources. For the purpose of this study, seven sources of income were enumerated. These include: Income from farm, Income from diversification, Income from working on another farm, Income from non-farm work, State Payments (such as family allowance, retirement/pension, benefits etc), pension from previous work and finally Income from other regular sources such as Interest and Rent. Equally households with no Regular Income were captured too. The summarized sources of income from the survey findings are as presented in Table 10.

Table 10: Major Sources of Income of Members of Household in the Last 12 Months

\begin{tabular}{|l|l|l|l|l|l|l|l|}
\hline $\begin{array}{l}\text { Income } \\
\text { from } \\
\text { Farm }\end{array}$ & $\begin{array}{l}\text { Income from } \\
\text { Diversification } \\
\text { Enterprises }\end{array}$ & $\begin{array}{l}\text { Income from } \\
\text { working in } \\
\text { another Farm }\end{array}$ & $\begin{array}{l}\text { Income } \\
\text { from } \\
\text { Non-farm } \\
\text { work }\end{array}$ & $\begin{array}{l}\text { State Payment } \\
\text { (Family } \\
\text { allowance, } \\
\text { Retirement, } \\
\text { Pension etc) }\end{array}$ & $\begin{array}{l}\text { Pension } \\
\text { from } \\
\text { previous } \\
\text { work }\end{array}$ & $\begin{array}{l}\text { Other } \\
\text { Regular } \\
\text { Sources } \\
\text { (Interest, } \\
\text { Rent) }\end{array}$ & $\begin{array}{l}\text { Non } \\
\text { Regular } \\
\text { Income }\end{array}$ \\
\hline 38.05 & 15.98 & 7.85 & 21.36 & 3.98 & 2.96 & 3.85 & 5.97 \\
\hline
\end{tabular}

The findings indicate that the main source of income from the respondents was from farming activities $(38.05 \%)$.

\section{Households Monthly Expenditure on Basic Needs}

The total monthly households expenditure (Table 11) was N3,005,290. Out of this amount, 73.4 percent was spent on food, 5.9 percent was spent on housing, 5.8 percent on transport, 4.7 percent on health, 6.6 percent on education, 0.7 percent on electricity, 0.3 percent on water, 2.2 percent on clothing and on security was 0.3 percent. 
The implication of this finding and the fact that a whopping 73.4 percent $(\mathrm{N} 2,204,405)$ was spent on food is that poverty incidence was high in the study area. This is deduced from Engle's law which states that the higher the incidence of poverty, the higher the proportion of the household expenditure on food.

Table 11: The Distribution of Monthly Expenditure on Basic Needs of Household

\begin{tabular}{llll}
\hline Items & Amount $(\mathrm{N})$ & $\begin{array}{l}\text { Average } \\
\text { Per/Income }\end{array}$ & $\begin{array}{l}\text { Percentage of total } \\
\text { Expenditure }\end{array}$ \\
\hline Food & $2,204,405$ & $5,511.0$ & 73.4 \\
Housing & 180,215 & 250.55 & 5.9 \\
Transport & 175,655 & 439.14 & 5.8 \\
Health & 140,185 & 350.5 & 4.7 \\
Education & 199,785 & 499.5 & 6.6 \\
Electricity & 20,755 & 51.89 & 0.7 \\
Water & 10,240 & 25.6 & 0.3 \\
Clothing & 65,320 & 163.3 & 2.2 \\
Security & 8.730 & 21.83 & 0.3 \\
Total & $3,005,290$ & $7,513.23$ & $99.9 \approx 100$ \\
\hline
\end{tabular}

\section{Analysis of the Poverty Status of Respondents}

Poverty line or poverty threshold is the basic lowest amount of money an individual needs to survive per day. In 1985, the World Bank set an International Poverty line at US \$1 per person per day. However, nations are expected to establish their own poverty line using either "cost of-basic-need (food and non-food items) methods, "food or dietary energy intake" or food-share method. (Ekong 2002). Another approach that is commonly used in Nigeria and which was employed in the study, involves taking an arbitrary proportion i.e two-third (2/3) and $(1 / 3)$ of the mean expenditure as poverty lines. Where, $1 / 3$ of the mean expenditure defines core poverty line and 2/3 mean expenditure represents the moderate poverty line (Nigeria Poverty Assessment Document, 1995).

In order to construct the poverty line of the study area, the total households surveyed were divided into deciles in ascending order of their expenditure. A deciles is any value which divides a set of data into 10 equal parts known as deciles and are denoted by D1, D2, D3....D10. each declie consisted of ten (10) households. The average total per capital household expenditure (PCHHE) on food and non-food items in each decile was then calculated, summed up at the end and divided by the total number of the sampled household to attain the Mean per capital household expenditure (MPCHHE). Therefore, two lines were then drawn from the mean per capita household expenditure representing two-third (2/3) (MPCHHE) and 1/3 (MPCHHE) to determine the poverty levels of the respondents. For instance, household spending more than two-third of the mean per capita household expenditure is considered to be extremely poor, and those households spending precisely or less than one-third of the mean per capita household expenditure are considered to be non-poor.

Each decile consists of ten (10) farm households expenditure. The total household expenditure is divided by the total number of people in an household to give per capital monthly expenditure which is N7,513.20.

\section{Poverty Levels of the Study Area}

i. Moderate Poverty Line: This is the two-third (2/3) of monthly per capital household expenditure (MPCHHE). The sum total of the mean monthly per capita household expenditure (MPCHHE) of the respondents was N7,513.20. 
Therefore, the moderate poverty line if the two-third of N7,513.20

$$
2 / 3 \times 7,513.20=5008.8=\mathrm{N} 5,010.0
$$

ii. Core Poverty Line: This is the one-third (1/3) of the mean monthly per capita household expenditure.

Core Poverty line $=1 / 3 \times 7,513.20=\mathrm{N} 2,504.2=\mathrm{N} 2,505$

The implication of these poverty levels is that any household in the study area with per capital monthly expenditure greater than or equal to N5,010 was considered to be non-poor, or rich while any household with per capital monthly expenditure below N5,010 was considered poor. Also, from the calculation above, the core poverty line or (one-third) MCPHHE was constructed or calculated to be N2,505. This means than any household in the study area with per capital monthly expenditure greater than N2,505 but less than N5,010 was considered to be moderately poor, but any household in the study area with per capita monthly expenditure below $\mathrm{N} 2,505$ was considered to be extremely poor.

\section{The Headcount Index of the Study Area}

The headcount index, which is a measure of number of the poor was calculated for moderate, core and non-poor poverty levels using a decile table that groups respondents into 40 (averaged income of 10 in each group) in an ascending order on income. .

The decile table shows that 28 percent of the total household sampled (i.e. 112) was below core poverty level. (The respondents could not spend more than N2,505 a month to buy the basic necessities of life. These households were considered as the extreme poor. The table also shows that $42 \%$ or 168 households were moderately poor, their monthly Consumption per person were below the poverty line of N5,010, but more than $\mathrm{N} 2,505$. In all, the analysis showed that 70 percent of the sampled households was relatively poor and could not attain the minimum standard of living. This leaves 30 percent of the total respondent households with per capita monthly expenditure equal to or higher than N5,010.

\section{The Poverty Gap Index of the Study Area}

The poverty gap index, or depth of an average moderate poor person below poverty line was 0.30 . In order words, the income transfer (shortfall) required to bring an average moderate poor person below the moderate poverty line was 0.30 , meaning that 0.30 of $\mathrm{N} 5.010$ which is $\mathrm{N} 1,503$ income transfer to the average moderate poor will bring him up to the poverty line. The poverty gap index for all the poor households sampled was 0.42 . This means that to bring an average core poor person of the study area to the moderate poverty line, an income transfer of 0.42 of N5,0 10 which is N2, 104.2 is required. Since the total number of the poor household in the study was 70 percent, then the average monthly amount required to be transferred to all the poor people in the study area to bring them up to the poverty line was 70\% multiplied by N5,010 which is N3,507.00 (N3,5 10). The implication here is that a lot still need to be done for the farmers in the state. Poverty alleviation measures should be aimed at improving the standard of living of the farmers. This can be achieved through subsidies of farming inputs, land improvement techniques, provision of basic infrastructure to enhance increased productivity and subsequently improved standard of living.

\section{Regression Result of Socioeconomic Characteristics Affecting Poverty of Households}

Table 12 revealed that the explanatory variables included in the model are significant in explaining changes in poverty incidence among the sampled households. The disaggregation analysis of the regression model illustrate that access to credit facilities from Micro-Finance Bank (MFB) (0.127), education (0.068), participation in agricultural workshops/seminars (0.617), constant access to remittances (0.351), livestock asset (0.513) and 
access to extension services (0.418) significantly reduce the probability of the household staying below the poverty line. These coefficients are significant at the 10,5 and $1 \%$ significance level respectively. Conversely, female head of household (0.469) as well as large household size (0.629) increases the probability of households remaining below poverty line. Although, not significant, distance to the market increase the probability of remaining below the poverty line. In addition though not significant in reducing poverty, are belonging to cooperatives, ownership to land title and engagement in non-farm activity as measured in time spent daily on nonfarm activity.

The coefficient of micro-credit (MFB) on reducing the probability of a household falling below poverty line is as expected and significant at $10 \%$. The significant effects of having access to credit facilities in lifting households out of chronic poverty is due to the ease with which such funds can be used in various activities in the household. The tangible nature of this credit allows borrowers to meet other consumption expenditures such as medical, school fees, food and social emergencies besides expenditures on productive inputs. In their survey conducted in Islamada, Lombok in Indonesia, micro credit was given to women who were under the poverty line and after one year, the average income of $90 \%$ of the beneficiaries had increased enough to move them out of poverty line (Grameen, BRAC and RD-12). Also, the work of Owuor (2007) and Khandker (1998) measured varying effects of micro credit programs on participants and found that informal borrowing reduces poverty by increasing per capita consumption among program participants. These authors also observed an increase in labour supply on farms, indicating that borrowers hired more labour.

On education, present findings indicate that better education have the effect of enabling households accessing and conceptualizing information on good farming methods, accessing better paying rural labour market and capable of profitably combining various enterprises. Therefore, education provides important indicators of household welfare and that raising poor household's access to education is likely to have beneficial effects on poverty alleviation and income distribution over the long run.

Households headed by females on the other hand had a higher probability of staying below poverty line, echoing the nature of structures of many rural communities in Africa. Majority of females in Africa have no legal right to property making them unable to offer asset securities in either credit or product markets. Such differential access to productive asset and inputs leads to inequality in welfare. Furthermore, with the rising migration of male to urban areas for higher paying jobs, this leads to a decline in agricultural production as women who are left to manage farms have less access to both improved inputs and credit markets given that they have lower accesses to collateral. Such gender gaps lead to static inefficiency and also reduce efficient investments in new technologies as well as in the maintenance and improvement of assets, particularly land. Consequently women led households continue to languish in poverty.

Results on involvement in non-farm activity translate to regular earnings from other labour employment and business investments. Given that agriculture is characterized by seasonal variations in production as well as longer production cycles many households diversify into non-farm investments with regular incomes, others also take off-farm employment as part time activities. For example a large proportion of farmers in the sample combine farming with some off-farm activities such as trading of manufactured goods, a factor that ameliorates persistence poverty.

Evaluation of land ownership against poverty shows that there exists a strong association between constrained landholding and rural poverty, suggesting that ownership of property such as land title enables households to easily have access to credit facilities, a factor that improves on cash investment in production with consequential reduction in poverty. An examination of access to land by different poverty categories in Nigeria indicates that the area of land cultivated is strongly associated with household per capita income. 
This also applies to assets such as livestock. In other parts of Africa livestock asset are widely used in preparation of land such as the case of ox-drawn ploughs which reduce expenditure on labour thus enabling timely land preparation. However, in Delta State, domestic livestock are reared for economic reasons. Hence sales from domestic livestock improve income availability.

Large family size, particularly under static income increases the risk of keeping households under chronic poverty. This is because with fixed income, the resources of the household are stretched over a large number of people.

Results on the effect of access to extension services indicate that agricultural productivity is important in ameliorating rural poverty. Thus exposure to modern farming techniques and good farm management principles can improve farm productivity and useful in ameliorating rural poverty. Similar findings have been reported in Latin America. The works of De Janvry and Sadoulet (2000) in Latin America established that rural poverty has a strong association with rural development through agriculture production, implying that agricultural potential has a role to play in poverty incidences. Results analysis that shows constant access to remittances reduces the probability of the household staying below poverty line. Constant reliance on remittances is however, not a good poverty intervention instrument as such remittances emanating mainly from siblings and other working relatives. The results however, indicate constraints in access to external financial resources, a factor that calls for increasing credit availability.

Table 12: Probit MLE of Determinants of Chronic Poverty

\begin{tabular}{llll}
\hline Variables & Coefficients & Std. error & t-value \\
\hline Access on MFB credit & -0.127 & 0.058 & $-2.19^{*}$ \\
Access to other credit & -0.038 & 0.116 & -0.33 \\
Age of head & -0.012 & 0.008 & -1.50 \\
Education of head & -0.617 & 0.013 & $-5.23^{* * *}$ \\
Seminars attendance & -0.617 & 0.193 & $-3.20^{* *}$ \\
If household head is female & 0.469 & 0.204 & $2.30^{*}$ \\
Ownership of land title & -0.203 & 0.191 & -1.05 \\
Remittances & -0.351 & 0.108 & $-3.25^{* *}$ \\
Hours spent on non-farm activity & -0.309 & 0.099 & $-3.12^{* *}$ \\
Belonging to cooperative & -0.018 & 0.012 & 1.50 \\
Distance to market & 0.015 & 0.006 & $2.60^{*}$ \\
Value of livestock assets & 0.513 & 0.196 & $-2.60^{*}$ \\
Access to extension & -0.418 & 0.113 & $-3.70^{* * *}$ \\
Family Size & 0.629 & 0.102 & $6.167^{* * *}$ \\
Intercept & 1.518 & 0.219 & $5.22^{* * *}$ \\
Log Likelihood & -418.21 & & \\
LR X2 & 112.85 & 0.315 & \\
Pseudo R2 & & & \\
\hline
\end{tabular}

\section{Profile of Poverty Based on the Characteristics of Poverty Levels}

The influence of the poverty levels of household on expenditure on food was analyzed through the distribution of the households by poverty levels. The result is presented in Table 13. The analysis shows that an average core poor spent 82.6 percent of his total expenditure on food and spent the remaining 17.4 percent on non-food items which in this study include: education, health, water, clothing, transportation, electricity, housing and security. 
An average moderate poor person expended 81.2 percent on food and 18.8 percent on other non-food items. On the other hand, the non-poor expended 71.5 percent on food and 28.5 percent on the remaining non-food items.

Relating these analyses to Engle's law; which states that the marginal propensity to consume food items decreases as income increases shows that the respondents' behaviour is as expected. However, the fact that the proportion of expenditure on food is still high (that is more than four-fifth (4/5) of the total expenditure) indicates that poverty incidence is high in the study area.

Table 13: Proportion of Household Expenditure on Food

\begin{tabular}{llll}
\hline Poverty Level & PCHHE $(\mathrm{N})$ & Food & Percentage \\
\hline Core Poor & $141,398.9$ & $116,833.5$ & 82.6 \\
Moderate Poor & $401,657.01$ & 326,252 & 81.2 \\
Non-Poor & $2,462,234.09$ & $1,761,319.5$ & 71.5 \\
Total & $3,005,290$ & $2,204,405$ & 72.4 \\
\hline
\end{tabular}

\section{Conclusion and Recommendations}

The Household survey on poverty index for households in Delta State, Nigeria was carried out and revelations are that there are differences in key indicators used to assess poverty across households, communities and local government areas. While there has been a creditable performance in some indicators assessed; such as education, infant mortality, others such as unemployment and income remain abysmally low.

Access to micro-credit, education, participation in agricultural seminars, livestock assets and extension services significantly reduce chronic poverty among rural households. On the other hand, female headed households and households located far away from local markets have a high probability of staying below chronic poverty line. Thus, these variables are significant in capturing the key rural poverty determinants. However, gender disparities in property rights has a consequence on poverty, as women empowerment through legal rights to property as key chronic poverty ameliorating factors among the farming communities.

\section{Recommendations}

Based on the findings of the study, the following recommendations are made:-

i. Government should intervene more aggressively in rural development through increased provision of rural infrastructure including construction of rural roads, water schemes, rural electrification and rural health schemes.

ii As regression result indicates that household size is significant and positively related to poverty, appropriate family planning awareness measures should be extended to rural dwellers by health workers and health related NGOs.

iii Improved Agricultural and Rural extension programme should be adequately packaged to provide rural dwellers with proper agricultural and vocational education so to enhance farmers' capabilities and improve production activities. 
iv The State Ministry of Education should maintain a regular inspection of schools especially in rural areas to ensure that teachers in the area attend school regularly and as well ensure that dilapidated schools are repaired and equipped with books laboratory equipment and other relevant instructional materials.

v Donor and intervention as well as other Aid agencies should channel most of energy in rural areas as this is where the bulk of the poor in the society lives. This will go a long way in uplifting them out of poverty.

\section{References}

Abumere S.I. (1998), 'Jurisdictional Partitioning and the poverty gap in Nigeria: Ibadan Working Paper Development Policy Centre

Adeoti AI, Adewusi OA (2005). Factors Influencing the Adoption of Soil Conservation Technologies in the Derived Savannah of Nigeria. Ibadan, J. Agri. Res.,, 1 (1) 39-47

Aliju, A. (2001), 'National Poverty Eradication Program (NAPEP), Conception, Implementation, Coordination and Monitoring'; Federal Ministry of Economic Planning Policy Paper, Abuja

Baulch, B. and Hoddinott, J. (2000), 'Economic Mobility and Poverty Dynamics in Developing Countries'; Journal of Development Studies 36-6:p.1-24

Baulch, B. and McCulloch, N. (1998), 'Being Poor and Becoming Poor: Poverty Status and Poverty Transitions in Rural Pakistan’ IDS Working Paper 79

Eweniyi, O. (2018), 'Nigeria is set to become the Poverty Capital of the World by 2018' http://www.konbini.com/ng/lifestyle/nigeria-poverty-capital-world-2018/ Retrieved July, 2018

Eze, C. M. (2009), The Privatized State and Mass poverty in Nigeria. The Factor of Economic Development Programme since 1980s, 'African Journal of Political Science and International Relations, Vol. 3 (10), pp.443450

Foster J., Greer J. and Thorbecke E. (1984), A Class Decomposable Poverty Measure; $\quad$ Econometrica 52 (2): 529-547

FOS (1999). 'Poverty Profile for Nigeria 1980 - 1996.' Federal Office of Statistics, Abuja, Nigeria

Grad, F. P. (2002). 'The Preamble of the Constitution of the World Health Organization'. Bulletin of the World Health Organization. 80 (12): 982

Greene W (2003). Econometrics Analysis 5th edition, Prentice Hall, New Jersey

Khandker R (1998). Fighting Poverty with Microcredit: Experience in Bangladesh. Oxford University Press, Inc. New York

Nigeria Bureau of Statistics (2011) 'Poverty Profile for Nigeria' NBS Office, Abuja, Nigeria

Okonjo-Iweala, N. Soludo, C. C., Muhtar, M. (2003) ,Introduction, 'in: N. Okonjo-Iweala, C. C.

Soludo, M. Muhtar (eds), The Debt Trap in Nigeria: Towards a Sustainable Debt Strategy, (Trenton, Africa World Press, Inc.), pp. 1-19

Owuor G, Ngigi M, Ouma A, Birachi E (2007). Determinants of Rural Poverty in Africa: The case of smallholder farmers in Kenya. J. Appl. Sci., 7(17): 2539-2543.

UNDP (2004), National Millennium Development Goals Report 2004- Nigeria (New York, Oxford University Press)

UNDP (2015), Delta State Development Performance: Health Sector Report; 1991- 2013; http://www.undp.org/content/dam/nigeria/docs/IclusiveGrwth/UNDPNGDeltaState_ Health2015.pdf 